\title{
A Linguistic Analysis of AEC News in an English Newspaper for Language Learning and Teaching
}

\author{
Praochompoo Kumsorn \\ Shinawatra University, Bangkok, Thailand \\ prawchompoo@hotmail.com
}

\begin{abstract}
An English newspaper, as an authentic English resource, provides a view of global knowledge and English usage in a physical world as it contains manifold issues and discourses valuable for English teaching and learning in a contemporary classroom. This study employed Systemic Functional Grammar of Halliday's approach to analyze texts of news linguistically. The purposes of the study were 1) to explore prevalent topics of AEC news as a reflection of Thailand and communicative purposes for the upcoming ASEAN Economic Community in 2015,2) to specifically analyze grammatical sentence structures used in an English newspaper aiming for English teaching and learning in Thai context. AEC news' articles were chosen for this study as it has become a considerably important event which shares multilateral information to ASEAN country members. The Nation newspaper was chosen for data collection for the period from January to August, 2013. Results showed that economics, tourism, and transportation were the most important topics and were reflective of Thailand's movement towards AEC. The news was mostly organized the idea by particular to general technique and mainly conveyed to the readers with informing as a communicative purpose. The most prevalent sentence structures were complex sentence. Active voice was more prevalent than Passive voice. The conclusion of the study was drawn descriptively. This study implicated that an English newspaper was beneficial for English teaching and learning as it contained a variety of language usage that could be used as a teaching material to improve students' grammatical and writing skills.
\end{abstract}

\section{Keywords: Systemic Functional Grammar, AEC, Authentic material, Grammar, Writing skill}

\section{Introduction}

Rationale: Newspapers are a printed media contributing to the society with features, advertising, and topics of interest (Manilerd, 1998) including local and international information covering different areas revolving around current situations. Moreover, newspapers bring the people knowledge with modern texts and discourses considered as contemporary language usage in the real world where English plays a vital part in education. Hence, an English newspaper could be used as an authentic material in an English classroom which aims to improve English learning and teaching in a Thai context. Authentic materials are defined by the linguistic scholar, Widdowson (1990) as "exposure to real language and its use in its own community". Likewise, Sanderson (1999) stated that "authentic materials are materials that we can use in the classroom and that have not been changed in any way for ESL students". An English newspaper serves as educational media which can be beneficial for English language teaching since it represents everyday situations that can motivate students' interest and provide real life elements to their experience and knowledge in numerous issues of the context of news. McDonough \& Shaw (1993); Rogers \& Medley (1988); Guariento \& Morley (2001); Chavez (1998); Richards (2001); and Brown (2002) agree that authentic materials would be advantageous to use in the classroom as a teaching aid and as a classroom activity for students who have sufficient English backgrounds to enjoy learning and reforming their English skills. This will allow them to be familiar with the use of English at a native speaker level for developing their English ability to a higher level.

AEC news' articles were chosen for the data analysis since The Association of South East Asian Nations (ASEAN) has given a new vision of ASEAN Economic Community (AEC) to achieve a higher level of economics, trade and investment including all significant areas as a single community and integration with ASEAN country members ("Asean.org," n.d., para. 1). Therefore, AEC has been recognized as a focal event for Thailand, as Thailand is one of the ASEAN members. A linguistic analysis of news would create a mutual understanding of AEC to the public and ASEAN country members. This study aimed to provide the information of AEC news in a newspaper that reflected Thailand's direction and movement on ASEAN Economic Community. Additionally, it was to consider the idea of using an English newspaper as 
authentic texts in a classroom as a way to motivate and to encourage students to learn English by using interesting topics and more advanced English in a newspaper. Below were the purposes of the study.

Purposes of the Study: This research aimed to analyze texts of news in The Nation using Systemic Functional Grammar approach with two following specific purposes:

- To explore prevalent topics and communicative purposes of AEC news as a reflection of Thailand for the upcoming ASEAN Economic Community in 2015.

- To specifically analyze sentence structures used in an English newspaper as an authentic material for English teaching and learning in the classroom.

Thus, this study attempted to find out:

Research question 1: What topics of AEC news are most prevalent in The Nation as a reflection to Thailand for the upcoming ASEAN Economic Community in 2015?

Research question 2: What organizations of idea and purposes are most prevalent as a written technique conveying AEC news through the newspaper?

Research question 3: What sentence structures and voices are most prevalent in AEC news?

Theoretical Background: "The aim has been to construct a grammar for purposes of text analysis: one that would make it possible to say sensible and useful things about any text, spoken or written, in modern English" (Halliday, 1994 p. 15).

Systemic Functional Linguistic (SFL) was a theory of Michale Halliday used as a theoretical framework for this study. Resources of Systemic Functional Grammar (SFG) were employed to analyze texts linguistically in a newspaper to specify the use of the language for communication. Systemic Functional Linguistic is mostly used in education for learning and teaching language functions and forms as it is a comprehensive way to teach students with levels of linguistics such as phonology, lexico-grammar, and semantics. It is addressed spoken and written discourses in sociological aspects to achieve communicative goals. Systemic Functional Grammar (SFG) was chosen for this study because it focuses on the real language usage in aspects of the world in which the language is "a systemic resource for meaning" (Bloor \& Bloor, 2004). SFL theory fits into a linguistic analysis of a newspaper since language usage in a newspaper is considered as a modern text. SFG provides a view of grammar as the option that the human uses to communicate with each other with meaningful clauses to accomplish their communicative purposes. Texts of news were analyzed following Systemic Functional Grammar methods which can show different aspects of language used in a newspaper.

\section{Literature Review}

Systemic Functional Grammar (SFG) of Michale Halliday was found in prior research studies and discussed as following. Van Dijk $(1977$, p. 6) introduces the term discourse topic as the gist, the kernel or the summary of text. Werlich $(1976$, p. 27) affirms that the thematic text base is a text initial linguistic unit". In another word, topic is a theme of the story which is summarized as a short term. Topic and theme are incorporated with each other to introduce a super corpus of the message. Lavid et al. (2012) studied "Genre Realized in Theme: The Case of News Reports and Commentaries" of two newspapers using thematic structure to analyze news' texts and found that certain thematic features are needed for each newspaper. "An extremely important aspect of functional grammar is the way information is structured in communication" (Bloor \& Bloor, 2004 p. 64). Humans think and impose what they would like to communicate or explain to others. The writer always plan on the written work or message before conveying it to the readers or getting it published for public consummation. McCabe \& Heilman (2007) studied "textual and interpersonal differences between a news report and an editorial" to show Systemic Functional Linguistics (SFL) to find out the use of textual adjuncts through choices in the system of appraisal that reviewed the writer's expectations towards the readers. In addition, Fahimeh \& Nabifar (2013) employed the theory of Systemic Functional Linguistic (SFL) to find out the process that Grammatical Metaphor describes the characteristics of nominalization in two genres of Health and Political Texts in the newspaper. The study reviewed that the journalist takes advantage of grammatical metaphor to write fewer clauses and words to express more messages through texts in a newspaper. Halliday's Functional Grammar underpins a communicative language teaching in the classroom. The tools of Functional Grammar have been widely used in newspapers' texts to show the language as a function for spoken and written discourses. The teachers of English can also use it as a theoretical model to teach both language function and form in different cultural contexts for foreign countries where English is used as a 
second language. Findings of linguistic analysis in an English newspaper would review a relationship between language function as communicative purposes and grammatical form as sentence structures for effective English wring and communication

\section{Methodology}

Population and Subjects: The population of this research was The Nation English newspaper since it sets AEC as a news category on the website and newspaper. Data was collected through www.nationmultimedia.com from January to August, 2013. The subjects were ninety four pieces of AEC news' articles related to Thailand.

Design of the Study: Design of the study employed Halliday's theory in Systemic Functional Linguistic to analyze headlines, leads and contents of news. Data was presented as percentages. Findings and conclusion were described qualitatively. The prior research of Pokasumrit (2009) was reviewed to determine for further study to broaden the area of linguistic analysis in a newspaper. Finally, the study was constructed in the area of linguistic analysis for language learning and teaching purposes, but it was different in terms of theoretical framework, data analysis and data presentation.

Data Analysis: Data was analyzed based on research questions of the study. Functional Grammar procedures of Halliday and Matthiessen (2004) were used to explore; topics of AEC news, organizations of idea and communicative purposes, sentence structures and voices. Descriptive statistics was employed to convert data from numbers to percentages. Below was the sample of text analysis in each linguistic level.

Theme and Rheme: Topic and theme are incorporated with each other to introduce the messages. In this study, headlines were analyzed by Halliday's approach. Theme and Rheme was a tool to identify a topic of news. Thematic features; Theme and Rheme are operated at the level of clauses in textual organization. Clauses are delivered with a combination of Theme and Rheme. Theme serves as the starting point of departure of the message (Halliday \& Matthiessen, 2004, p. 64). Theme is the first part of the message, accompanied by Rheme which is the rest of the message. The sample of headlines was presented in bold to signify the topic of news below.

\begin{tabular}{lll}
\hline Theme & Rheme & Topic \\
\hline Foreigners & eager to invest in waste-to-energy & Economic \\
Mekong nations & urged to protect migrant workers & Migrant worker \\
\hline
\end{tabular}

According to the above demonstration, Theme was a subject of the message or called Nominal group identifying the actor of the clause. Rheme is the focus of the message telling what is going on in the clause. For the first headline, "Foreigners eager to invest in waste-to-energy", the starting point of the message was 'Foreigners' (Subject) would like to 'invest' (verb) 'in waste-to-energy'. The rest of the message 'eager to invest in waste-to-energy' was the rheme telling the main action focusing on the investment. Therefore, this headline was considered under Economic topic (see Appendix). Likewise, "Mekong nations urged to protect migrant workers", Theme was Mekong Nations and Rheme focused on a migrant worker issue. This was under Migrant worker and Refugee topic (see Appendix).

Information Structure: Information structure is the process in which the information is constructed in communication which is concerned with Given and New procedure. Given information is known as shared knowledge in which the writer or speak grabs the people attention by wording or clauses at the beginning of messages such as headlines in the newspaper. New information refers to the focus of messages. This element of functional grammar was used to analyze contents of news in order to specify how texts are constructed to identify organization of idea and communicative purposes by the writer. Below was the sample of analysis based on Given and New procedure.

\section{GIVEN: More VN tourists choose Thailand}

Paragraph 1: The number of Vietnamese tourists visiting Thailand has jumped tenfold in the past 12 years, rewarding the efforts of the Thai government to attract more visitors from that country.

Paragraph 2: According to the Tourism Authority of Thailand's Ho Chi Minh City office, more than 530,000 Vietnamese visited Thailand in the first 10 months of last year. 
Paragraph 3: In 2000, the number was a mere 57,000. Paragraph 4: Vietnam is the 13th-largest tourism market for Thailand. Vietnamese tourists are fairly big spenders, said Chutathip Chareonlarp, director of the TAT office in Ho Chi Minh City ("More VN tourists choose Thailand," 2013)

Writers usually convey the important information at the beginning of texts. Above news messages were analyzed based on Given (headline) and New (lead and body). Given refers to the clause of the headline "More VN tourists choose Thailand", it was shared or mutual information given by the writer to direct the readers' attention to the main topic of messages. This level of analysis focused on New or the body of texts. The organization of idea and communicative purpose were identified from Paragraph 2, 3 and 4 . In paragraph 2, the keyword was "according to', the writer stated the evidence referring to the Tourism Authority of Thailand's Ho Chi Minh City office to present the information. In paragraph 3, the clause "In 2000, the number was a mere 57,000" stated the fact of the information. In paragraph 4, the information was reported by referring from the person as seen in the clause "said Chutathip Chareonlarp, director of the TAT office in Ho Chi Minh City". According to the above analysis, "fact and evidence" was presented as the organization of idea and "informing" was the purpose of communication as referred from Paragraph 1, 2,3 and 4.

Sentence Structure: Dependent and independent clauses were identified to find out what sentence structures are used in each piece of news. Simple, compound, complex and compound-complex were classified in this study. Below was a sample of sentences found in the articles of AEC news.

Sentence 1: "Construction of a yard to store containers and lifting facilities will begin at the end of this year". (Laos and Thailand to have freight rail link by 2015," 2013)

\begin{tabular}{lll}
\hline Sentence & Independent clause & Dependent clause \\
\hline Simple & $\begin{array}{l}\text { Construction of a yard to store containers and lifting } \\
\text { facilities will begin at the end of this year". }\end{array}$ & - \\
\hline
\end{tabular}

This was a simple sentence as it consisted of a Nominal group "Construction of a yard to store containers and lifting facilities and one main verb "begin". It was a complete sentence that can stand alone as an independent clause.

Sentence 2: "The project which was supposed to start in 2011, has been delayed". (Laos and Thailand to have freight rail link by 2015," 2013)

\begin{tabular}{lll}
\hline Sentence & Independent clause & Dependent clause \\
\hline Complex & The project has been delayed & which was supposed to start in \\
& & 2011 \\
\hline
\end{tabular}

This was a complex sentence. "The project has been delayed" was an independent clause connected with dependent clause "which was supposed to start in 2011" by the dependent marker "which", was a modifier of the subject "the project.

Active and Passive Clauses: In functional grammar, voices are known as active and passive clauses. Passive clauses are inverted form of active clauses. Active and Passive clauses were identified based on Halliday's functional grammar. The term 'process' and 'participant' were involved to specify Actor and Goal in active and passive clauses. Process refers to the verbal group. Actor refers to a performer or subject. Goal is the point of impact. Active and Passive voices were identified to see which one are most prevalent in the newspaper. Below was the sample of active and passive forms identified as Actor, Process and Goal. "The older ASEAN member countries - Brunei, Thailand, Singapore, Malaysia, Indonesia and the Philippines - have been reducing import tariffs to zero since 2010, opening up the regional export market". ("Laos has until 2018 to cut tariffs for Afta," 2013)

\section{Active}

\begin{tabular}{lll}
\hline The older ASEAN member countries - & have been reducing & import tariffs to zero since \\
Brunei, Thailand, Singapore, Malaysia, & & 2010, opening up the regional \\
Indonesia and the Philippines & export market \\
Actor & Process & Goal \\
\hline
\end{tabular}


This was an active voice because the clause "The older ASEAN member countries - Brunei, Thailand, Singapore, Malaysia, Indonesia and the Philippines" was a performer (subject) doing the action "have been reducing" (a verbal group with a transitive verb 'reducing') which has a goal or the impact of the action "import tariffs to zero since 2010, opening up the regional export market" (object). "They will be executed by lethal injection in the city of Kunming in Southwest China's Yunnan province". ("Mekong river murderers to be executed in China today," 2013)

\begin{tabular}{lll} 
Passive & & \\
\hline They & will be executed & $\begin{array}{l}\text { by lethal injection in the city of Kunming in Southwest China's } \\
\text { Yunnan province }\end{array}$ \\
Goal & Process & Actor
\end{tabular}

Conversely, Goal referred to "they" (subject) the people who received the impact from Process "will be executed" (verbal group) performing by Actor "by lethal injection in the city of Kunming in Southwest China's Yunnan province" which was a passive form.

\section{Results}

A total of ninety four pieces of news was analyzed linguistically in this study. There were twelve pieces of news in January (12.76 \%), nine pieces of news in February (9.57\%), twelve pieces of news in March (12.76 \%), seven pieces of news in April (7.45 \%), seven pieces of news in May (7.45\%), fifteen pieces of news in June (15.96\%), seven teen pieces of news in July (18.09\%) and fifteen pieces of news in August $(15.96 \%)$. Results of the study were presented based on the research questions.

Research question 1: What topics of AEC news are most prevalent in The Nation as a reflection of Thailand for the upcoming ASEAN Economic Community in 2015? In order to answer this research question, AEC news was categorized to find out the prevalent topic presenting in The Nation. The analysis could define what area of AEC that Thailand had been moving on and in cooperation with ASEAN country members. Headlines of ninety four news articles were analyzed to identify a topic of news. Topics were identified based on theme and rheme procedure. Below bar chart showed the overall results of the topics presented in The Nation during January to August 2013.

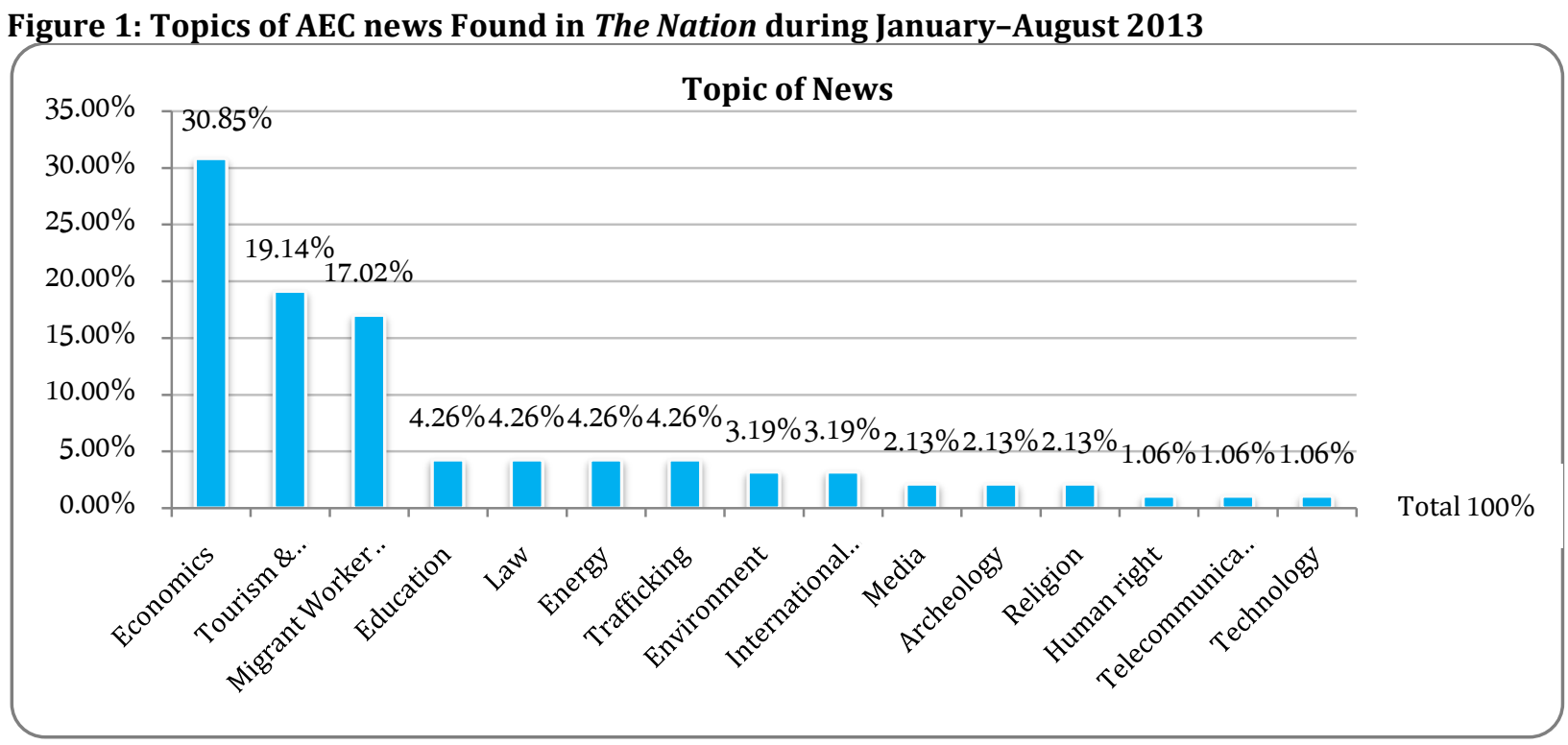

According to the above data, there were fifteen topics under AEC news. Data was ranked by percentage respectively. The topics were economics $(30.85 \%)$, tourism and Transportation (19.14\%), migrant worker and refugee (17.02\%), education (4.26\%), law (4.26\%), energy (4.26\%), trafficking (4.26\%), environment (3.19\%), international relations (3.19\%), media (2.13\%), archeology (2.13\%), religion (2.13\%), human right (1.06\%), telecommunication (1.06\%) and technology (1.06\%). The top three prevalent topics of AEC news in The Nation were economics, tourism and transportation followed by migrant worker and refugee. This showed that economics, tourism and transportation issues were the 
most important areas that Thailand had focused on while migrant worker and refugee were the next prevalent topic revealed as being another key issue between Thailand and neighboring countries (see Appendix).

Research question 2: What organizations of idea and purposes are most prevalent as a written technique conveying AEC news through the newspaper? To answer this research question, each piece of news was analyzed based on Given and New procedure. Data was divided into 2 sections: 1) each type of organization of idea was classified as particular to general, general to particular, problem and solution, cause and result, fact and evidence including comparison and contrast, 2) communicative purposes were categorized as informing, agreement, appeal for action, complaint, and disagreement. Below bar chart showed the prevalent organizations of idea found in The Nation during January to June 2013. Data was ranked by percentage.

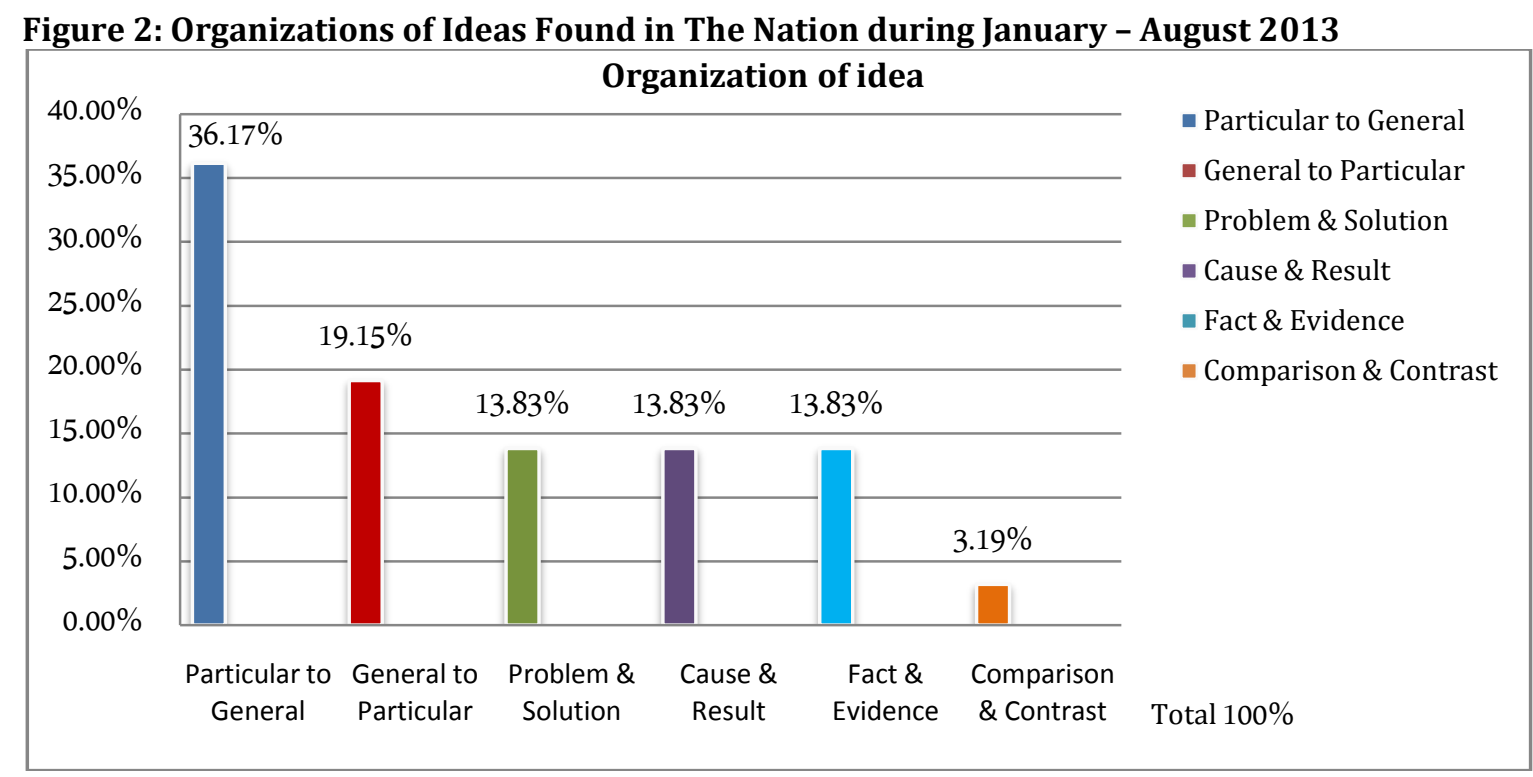

According to above chart, the writers mostly organized the news contents by particular to general (36.17 $\%$ ) followed by general to particular (19.15\%), problem and solution (13.83 \%), cause and result (13.83 $\%$ ), fact and evidence (13.83\%) and comparison and contrast (3.19\%). Particular to General was mostly found in economic topics while General to Particular was mostly found in tourism and transportation topics. Problem and Solution along with Cause and Result were mostly found in the Migrant worker and Refugee topic. Finally, Comparison and Contrast was mostly found in the economic topic (see Appendix). Below bar chart was the result showed the prevalent communicative purposes found in The Nation during January to August 2013. Data was ranked by percentage.

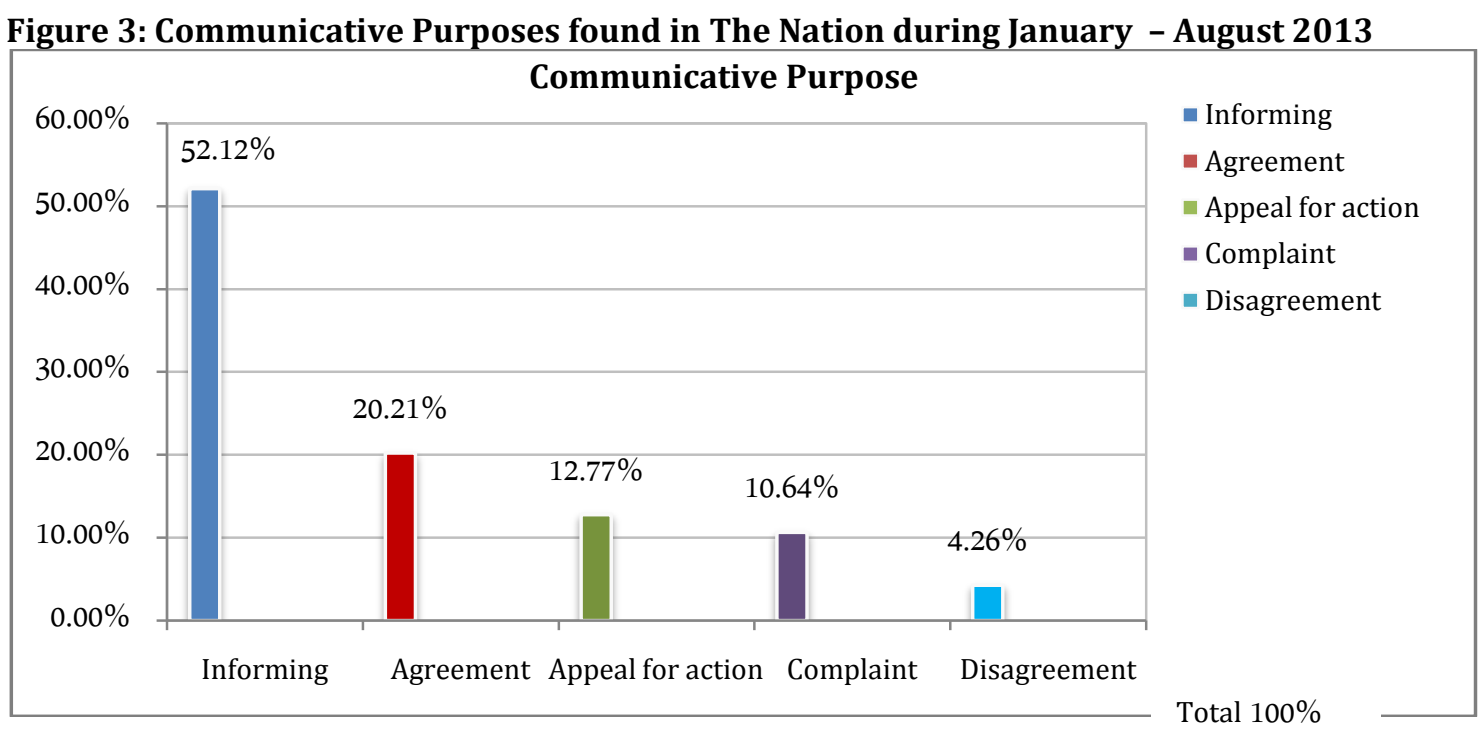


Based on above results, the writer mostly communicated the purpose of news to readers by informing (52.12\%), agreement (20.21\%), appeal for action (12.77\%), complaint (10.64\%) and disagreement (4.26\%) respectively. Informing and Agreement were a communicative purpose that the writer mainly conveyed to the audience and mostly found in economic topic (see Appendix). Appeal for action and Complaint were the next purpose mostly found in religion, migrant worker and refugee topics as they usually appears in the controversial issue that needs a resolution (see Appendix). Disagreement was used when the writer wished to state a contradict point of view in the messages.

Research question 3: What sentence structures and voices are most prevalent in AEC news? To answer this research question, simple, compound, complex and compound-complex sentences were identified in each piece of news. Voices were identified as active and passive forms. There were one thousand three hundred and nine sentences in total from ninety four pieces of news. Below bar chart presented the most prevalent sentence found in The Nation during January to August 2013.

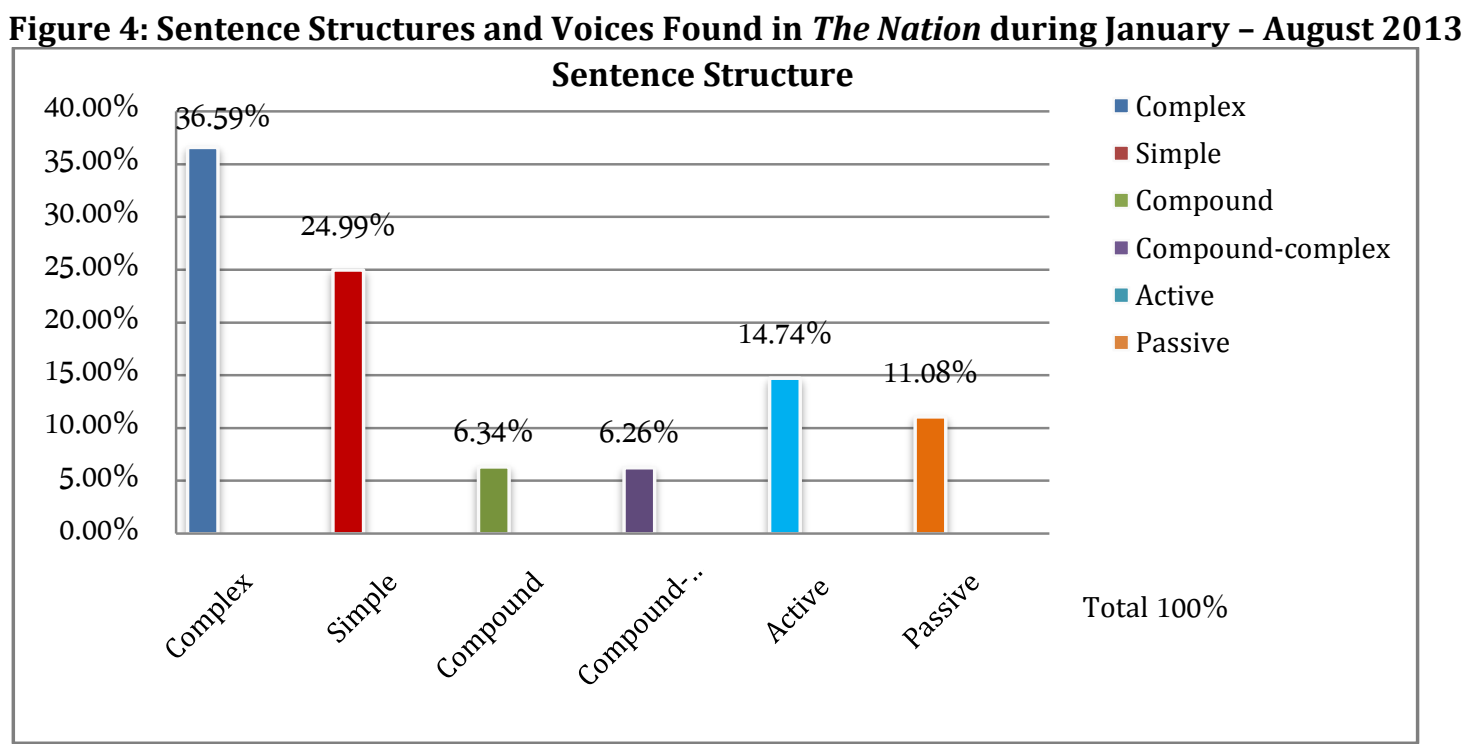

According to the above data, the most prevalent sentence was complex (36.59\%), simple (24.99\%), compound (6.34 \%) and compound-complex sentences (6.26\%) respectively. Active voice (14.74 \%) was slightly over than passive voice (11.08\%). This showed that an English newspaper provided a variety of English sentences as a grammatical structure in The Nation which is useful for improving grammar learning for a better English writing and communication.

Discussion: The results of this study lend support to the findings of prior studies; (e.g., Pokasumit, 2009; Lavid et al., 2012; McCabe \& Heilman, 2007 and Fahimeh \& Nabifar, 2013). These studies also utilized linguistic and functional grammar analysis in newspapers with varying purposes in language for communication. The frequent topic of AEC news manifested in The Nation signified the important issues happening at that period of time. The news is usually written by providing the most important information first and through to the least important information (van Dijk, 1988). Similarly, AEC news in The Nation was mostly constituted by particular to general technique to lead the audience with the major event at first before stating minor details. Complex sentences were mostly found in The Nation which indicated that the writer tried to shorten messages using the complex sentence to reduce space in order to give more information to the audiences. Active voice was mostly used in The Nation as a writer gave emphasis on Actor as a person doing the action. For English pedagogy, this study implicated that an English newspaper provides different views of language usage in a level of native speakers and a variety of sentences that could be used in teaching grammatical and written skills. This would help students to experience with English in a real life context using a newspaper as an educational source.

\section{Conclusion}

This research paper reported the findings of a Systemic Functional Grammar's analysis. Theme and Rheme as a feature of clauses could textualize headlines' structures to find out each topic as a focal theme of the news' messages. Findings showed that the most prevalent topics of AEC news were economics, 
tourism and transportation. This reflected that economic issues were a significant agenda that Thailand has been coping with and it fitted into ASEAN Economic Community's objectives which aim to upgrade a higher level of economics and investment with ASEAN country members as a single market and product base ("Asean.org," n.d., para. 1). Migrant worker and refugee were the next prevalent topic given the view of neighboring counties' expectation of Thailand's resolution for migrant workers' right and legality (see Appendix). Given and New was thoroughly used to find out the focus of messages that the writer was trying to convey to the audiences. The findings disclosed that the writer mostly constructed texts by Particular to General technique stating specific information in the news before describing other relevant information while General to Particular technique provided general information introducing the news before describing the major focus of messages. Problem and Solution technique was used when the writer try to imply problematic issues within news' texts which usually come with the solution in the messages. Cause and Result was similar but different from Problem and Solution technique as it provided the culprits of the issue with effects or results, but without the solution in the messages. Fact and Evidence provided the information with reference and evidence to make the information more reliable and upright. Comparison was used to compare two similar things and it was found in a few articles of news for this study. Communicative purposes of news yielded the intention of the writer in providing information to the public as the news always has that expectation (Fairclough, 1995, p. 204). This study revealed that the writers mostly provided AEC news informatively by informing as a communicative purpose.

Suggestion for Future Study: Systemic Functional Grammar could be used as a tool for textual analysis in other issues of newspapers or other authentic sources as it provides a wide range discipline for a profound grammatical analysis useful for researchers to inquire structures of language as a feature for communication.

Acknowledgements: The author would like to thank Dr. Steve Mckee for his copyediting the original manuscript and assistance as a research supervisor. All errors are the author's.

\section{References}

Association of Southeast ASEAN Nations. (n.d.). ASEAN Economic Community. Retrieved March 25, 2014, from http://www.asean.org/communities/asean-economic-community

Bloor, T. \& Bloor M. (2004). The functional analysis of English: A Hallidayan Approach (2nd ed). London: Hodder Arnold.

Brown P. C. (2002). The Newspaper: A Materials Writer's Gold Mine. The Newsletter of the JALT Materials Writers $S I G, 10(1), 2-9$.

Chavez, M. (1988). Learner's perspectives on authenticity. International Review of Applied Linguistics in Language Teaching, 36(4), 277-306.

Fahimeh, T. \& Nabifar, N. (2013). A Comparative Study of Ideational Grammatical Metaphor in Health and Political Texts of English Newspapers. Journal of Academic and Applied Studies, 3(1), 32-51.

Flairclough, N. (1995). Media Discourse. Great Britain: Edward Arnold.

Guariento, W. \& Morley, J. (2001).Text and task authenticity in the EFL classroom. ELT Journal, 55(4), 347-353.

Halliday, M. A. K. (1994). Introduction to Functional Grammar (2nd ed). London: Edward Arnold.

Halliday, M. A. K. \& Matthiessen, C. (2004). An introduction to functional grammar (3rd ed.). London: Hodder Education.

Laos and Thailand to have freight rail link by 2015. (2013). The Nation, Retrieved from http://www.nationmultimedia.com/aec/Laos-and-Thailand-to-have-freight-rail-link-by-20130199303.html

Laos has until 2018 to cut tariffs for Afta. (2013). The Nation, Retrieved from http://www.nationmultimedia.com/aec/Laos-has-until-2018-to-cut-tariffs-for-Afta30197517.html

Lavid, J., Arús, J. \& Moratón, L. (2012). Genre Realized in Theme: The case of news reports and commentaries. Discours: Revue de linguistique, psycholinguistique et informatique. Retrieved from http://discours.revues.org/8623. DOI: 10.4000/discours.8623.

Manilerd, V. (1998). Print Media in ASEAN 1998, ASEAN Studies Publications Series. Phase I-c: Thailand: Asean Committee on Culture and Information.

McCabe, A. \& Heilman, K. (2007). Textual and interpersonal differences between a news report and an editorial. Revista Alicantina de Estudios Ingleses. 20, 139-156.

McDonough, J. \& Shaw, C. (1993). Materials and methods in ELT. Oxford: Blackwell. 
Mekong river murderers to be executed in China today. (2013). The Nation, Retrieved from http://www.nationmultimedia.com/aec/Mekong-river-murderers-to-be-executed-in-China-tod30200973.html

More VN tourists choose Thailand. (2013). The Nation. Retrieved from http://www.nationmultimedia.com/aec/More-VN-tourists-choose-Thailand-30197215.html

Pokasamrit, P. (2009). A Sociolinguistic and Pragmatic analysis of the letters to the editor in the Post Bag column of the Bangkok Post. NIDA Development Journal, 49(3), 187-220.

Richard, J. C. (2001). Curriculum development in language teaching. Cambridge: Cambridge University Press.

Rogers, C. V. \& Medley, F. W., Jr. (1988). Language with a purpose: Using authentic materials in the foreign language classroom. Foreign Language Annals, 21, 467-478.

Sanderson, P. (1999): Using Newspapers in the Classroom. Cambridge: Cambridge University Press.

Van-Dijk, T. A. (1977). Text and Context: Explorations in the semantics and pragmatics of discourse. London: Longman.

Van-DijK, T. A. (1988). News as Discourse. Hillsdale, NJ: Lawrence Erlbaum Associates.

Werlich, E. (1976). A text grammar of English. Heidelberg: Quelle \& Meyer.

Widdowson, H. (1990). Aspects of Language Teaching. Oxford: Oxford University Press.

\section{APPENDIX: Headline, Organization of Idea and Purpose in Each Topic of News}

\begin{tabular}{|c|c|c|c|c|}
\hline \multirow{2}{*}{$\begin{array}{l}\text { Topic } \\
\text { Economics }\end{array}$} & \multirow{2}{*}{$\begin{array}{l}\text { Headline } \\
\text { Foreigners eager to invest in waste-to-energy }\end{array}$} & \multicolumn{2}{|c|}{$\begin{array}{l}\text { Organization of } \\
\text { idea }\end{array}$} & \multirow{2}{*}{$\begin{array}{l}\text { Purpose } \\
\text { Informing }\end{array}$} \\
\hline & & $\begin{array}{l}\text { General } \\
\text { Particular }\end{array}$ & to & \\
\hline & Laos has until 2018 to cut tariffs for Afta & $\begin{array}{l}\text { Particular } \\
\text { General }\end{array}$ & to & Informing \\
\hline & Seafood export row & $\begin{array}{l}\text { Particular } \\
\text { General }\end{array}$ & to & Disagreement \\
\hline & Rice export sees almost two fold growth & $\begin{array}{l}\text { Comparison } \\
\text { Contrast }\end{array}$ & and & Informing \\
\hline & $\begin{array}{l}\text { Central to open department store in new mall } \\
\text { in Jakarta }\end{array}$ & $\begin{array}{l}\text { General } \\
\text { Particular }\end{array}$ & to & Agreement \\
\hline & Ministers kick off ACMECS meeting in Laos & $\begin{array}{l}\text { Particular } \\
\text { General }\end{array}$ & to & Informing \\
\hline & MOU on contract farming signed & $\begin{array}{l}\text { Particular } \\
\text { General }\end{array}$ & to & Agreement \\
\hline & Thais push for regional rice cooperation & $\begin{array}{l}\text { Particular } \\
\text { General }\end{array}$ & to & Informing \\
\hline & Big C helps promote OTOP products & $\begin{array}{l}\text { Particular } \\
\text { General }\end{array}$ & to & Agreement \\
\hline & Internet helps rewire Asian economies & Fact and Evidenc & & Agreement \\
\hline & Many I'nesian firms not aware of AEC & $\begin{array}{l}\text { Problem } \\
\text { Solution }\end{array}$ & and & $\begin{array}{l}\text { Appeal for } \\
\text { action }\end{array}$ \\
\hline & More Singaporeans here for nip 'n' tuck & $\begin{array}{l}\text { General } \\
\text { Particular }\end{array}$ & to & Informing \\
\hline & A $10 \%$ more millionaires in city-state & Fact and Evidenc & & Informing \\
\hline & Global slump hits Laos' coffers & Cause and Result & & Informing \\
\hline & Japanese firms boost presence in the region & $\begin{array}{l}\text { General } \\
\text { Particular }\end{array}$ & to & Agreement \\
\hline & Philippines to import 187,000 tonnes of rice & $\begin{array}{l}\text { Particular } \\
\text { General }\end{array}$ & to & Informing \\
\hline & $\begin{array}{l}\text { Myawady checkpoint swamped by Thai } \\
\text { goods }\end{array}$ & Cause and Result & & Complaint \\
\hline & Dengue fuels coconut-juice fever in Laos & $\begin{array}{l}\text { Particular } \\
\text { General }\end{array}$ & to & Agreement \\
\hline & Investors drawn to pharmaceutical market & $\begin{array}{l}\text { General } \\
\text { Particular }\end{array}$ & to & Informing \\
\hline & Pertamina eyes Thailand assets & $\begin{array}{l}\text { General } \\
\text { Particular }\end{array}$ & to & Informing \\
\hline
\end{tabular}


Indian companies to make up for lost time with \$2.6-bn investment

Hopes slim for Jakarta's 'green goods'

Thailand made up $90 \%$ of foreign investment in June

Talks with Thailand for a new border trade centre

Dawei Deep Sea Port project 'will not be controlled by Thailand'

Malaysia swift to meet Asia's growing hunger for bird's nests

Laotian egg farms hit by Thai imports

Thailand 4th-biggest investor in actual terms

Japan shifting investment to Southeast Asia

Tourism \& Laos and Thailand to have freight rail link by Transportation

Acmecs action plan highlights transport and tourism

Laos mulls single visa to cover region

Regional economic strategy 'hinges on transport'

Border development zones and transport links to be discussed in Phnom Penh

Myanmar joins bandwagon for common

Asean visa

Minh: Connectivity is key to Asean's tourism plans

More VN tourists choose Thailand

Laos vows troubled Asean rail link will not hit the buffers

Travel agencies urged to broaden focus to Asean

\begin{tabular}{ll}
\hline Topic & Headline \\
\hline $\begin{array}{l}\text { Tourism \& \& } \\
\text { Transportation } \\
\text { project } \\
\text { Thailand, China lead Yangon tourism market } \\
\text { More Myanmar nationals travelling abroad }\end{array}$ & $\begin{array}{l}\text { Mgency, Thai group to study deep-sea port } \\
\text { growth in Southeast Asia } \\
\text { Three new international carriers to fly direct }\end{array}$
\end{tabular}

Plans hatched for two new deep-sea ports Four border checkpoints to be opened to all this week

Lao rail web stretching further into Thailand

Migrant

worker

Refugee
Mekong nations urged to protect migrant \& workers

Laotians told to register in Thailand

Migrant workers send Bt37 billion home a
Comparison

and Informing

Contrast

Particular

to Disagreement

General

Fact and Evidence Informing

Particular

to Informing

General

Particular to Informing

General

Fact and Evidence Informing

Cause and Result

Complaint

Fact and Evidence

Comparison and

Informing

Contrast

Agreement

General

to Informing

Particular

Particular

General

Particular

General

General

Particular

Particular

General

General

Particular

Problem

to Agreement

to Agreement

to Agreement

to Informing

to Agreement

Solution

Fact \& Evidence

and Agreement

Problem \& Solution

Informing

Disagreement

General

Particular

to Appeal for action

Organization of Purpose

idea

Particular

to Informing

General

Fact and Evidence Informing

General

Particular

General

to Informing

Particula

to Informing

General

Particular

to Informing

Fact and Evidence

Particular

Informing

General

Particular

to Informing

General

to Informing

Problem

and

Appeal for

Solution

action

Cause and Result

Fact and Evidence
Informing Informing 
year

Workers trapped in border town

'Legal vacuum' on Rohingya

Many Laos workers quit southern provinces

Myanmar migrant workers become jobless while officially documented

Thailand asks Laos to help legalized 56,000 overseas workers

Thailand deports over 1,000 per month

Agencies recruiting people for work overseas warned they face 'penalties'

Workers to get advice

UN promises no forced repatriation

The 'forgotten' million

Minister voices concern about workers living in Thailand

Locals upset over unequal pay system

Many migrant workers paying for bogus visa extensions

Education

Law

Energy
Ministers agree to forge Asean education links ahead of AEC

Yangon and Thai varsities sign pact

Thai students learn traditional dances

Chula offers funding

Anand urges Vientiane to find missing activist

ASEAN MPs press Laos on Sombath

M'sian court rules Laos not obliged

Mekong river murderers to be executed in China today

Big rush to complete Yangon power plant Green light for PTT's \$27-bn Vietnam project

New natural-gas plant opened

Dawei seeks Japanese input
Problem

Solution

Problem

Solution

Problem

Solution

Cause and Result

Particular

General

Problem

Solution

Particular

General

General

Particular

Problem

Solution

Cause and Result

Fact and Evidence

Cause and Result

Particular

General

General

Particular

Particular

General

Particular

General

Particular

General

Particular to genera

General

Particular

Cause and Result Informing Particular to general Informing

Cause and Result

Particular

General

Particular

General

Particular

General
Informing

to Agreement

to Informing

and Informing

and Appeal for action

and Complaint

Informing

to Appeal for action

and Informing

to Informing

to Appeal for action

Complaint Complaint

Complaint

to Informing

to Agreement

to Informing

to Informing

to Informing

Appeal for action

to Complaint

to Informing 


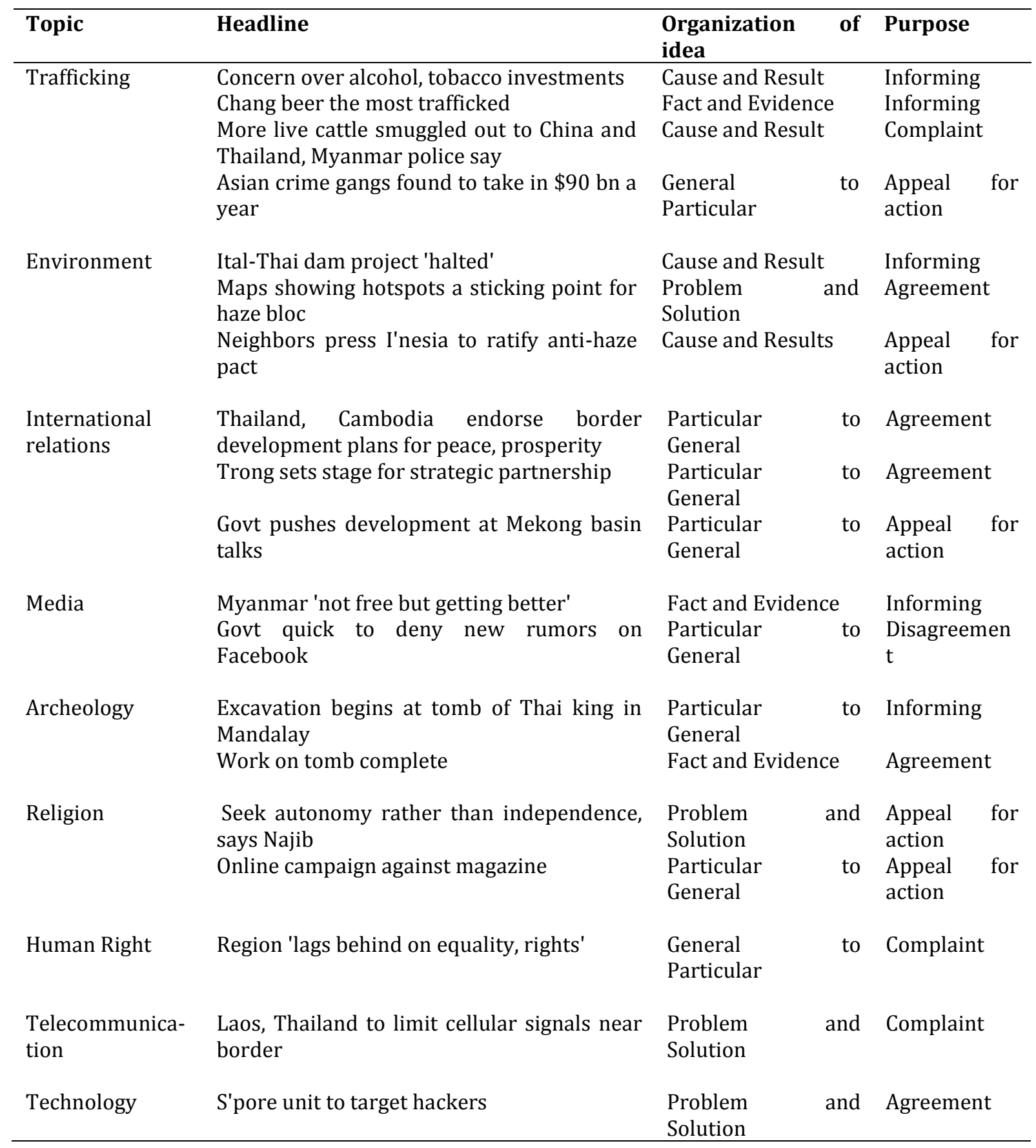

